\title{
DINNYÉS PATRIK
}

\section{NAGYHATALMI AMBÍCIÓK II. JÓZSEF ÉS II. KATALIN SZEMÉLYES BESZÉLGETÉSEIBEN (1780) ${ }^{1}$}

A kora újkorban a Magyar Királyság nem folytathatott önálló külpolitikát, hanem sok esetben inkább a dinasztikus érdekeket szolgáló Habsburg célkitűzések alá rendelődött. Mária Terézia (1740-1780) uralkodása alatt előbb az osztrák örökösödési (1740-1748), majd a hétéves háborúval (1756-1763) értékelődött fel a Magyar Királyság helyzete, hiszen a Habsburg diplomácia a poroszok felemelkedése miatt egyre inkább Európa keleti és déli része felé volt kénytelen tekintetni. II. József (1765/1780-1790) - bár nem adta fel az évszázados Habsburg külpolitikai célokat sem (befolyás növelése a Német-római Császárságban) - figyelme egyre tudatosabban fordult kelet, majd dél felé. Ennek első állomása a Rzeczpospolita első, 1772-es felosztása, aminek eredményeképpen a Habsburg Monarchia megszerezte Galíciát és Lodomériát ${ }^{2}$ (a felosztás nyitányaként a lengyeleknek korábban elzálogosított szepességi területeket), majd az 1768-1774 közötti orosz-török háborúban való közvetítői szerep jussaként 1775-ben Bukovinát. A nyugati kudarcokkal szemben keleten sikereket könyvelhetett el a Habsburg külpolitika. A császár külpolitikai célkitűzéseit II. Katalin (1762-1796) támogatásával kívánta elérni, aki pedig az említett orosz-török háború után az 1780-as években ismét tudatosan tekintett Konstantinápoly felé. II. József 1780-ban az Orosz Birodalomba indult, hogy II. Katalint megnyerje poroszellenes külpolitikai elképzeléseinek. Akkor még nem tudhatta, hogy nem a Bécsben mindig szem előtt tartott nyugati érdekek erősítéséhez nyeri el II. Katalin támogatását, hanem idővel ő lesz majd az, aki Szentpétervár törökellenes terveihez csatlakozik.

II. József 1780 tavaszán indult Mogiljovba, a császártalálkozó tervezett helyszínére. ${ }^{3}$ A császár útja először Galíciába vezetett, aminek határát (egyben a

1 The article is written with financial support of the joint project of the Russian Foundation for Basic Research and the Foundation for Support of the Russian Language and Culture (Hungary) "The Habsburg Monarchy: new trends in research of economic, sociopolitical and national development of the Central-European composite state", No 19-59-23005.

2 Galícia és Lodoméria helyéről és szerepéről a Habsburg Monarchiában: Gebei Sándor: Halics-Lodoméria királyság, a Habsburgok 18. századi új szerzeménye. In: Hagyomány és történelem. Ünnepi kötet Für Lajos 70. születésnapjára. Szerk.: Gebei Sándor. Eger, Líceum Kiadó, 2000. 215-238.

3 Az utazásról eddig legrészletesebben: Петрова, М. А.: Екатерина II. и Иосиф II. Формирование российско-австрийского союза 1780-1790. Москва, Наука. 2011., Бессарабова, Н.В.: Путешествия Екатерины Великой по России: от ярославля до Крыма. Москва, Эксмо, 2014. Magyar nyelven: Dinnyés Patrik: Mogiljovtól Szmolenszkig. II. József német-római császár és II. Katalin orosz császárnő első találkozása és közös utazása (1780) In: AETAS 34 évf. (2019) 3. sz. 37-63. 
Habsburg Monarchia külső határát) átlépve „átváltozott" Falkenstein grófjává, ugyanis II. József innentől már inkognitóban utazott. ${ }^{4}$ Jelen tanulmányban az első út során váltott, külpolitikai vonatkozású beszélgetéseket vesszük vizsgálat alá. N. V. Besszarabova a két uralkodó beszélgetéseit kronológia alapján három részre osztotta: (1) mogiljovi tartózkodás; (2) a Mogiljovból Szmolenszkbe vezető út; (3) a Szentpéterváron töltött idő. ${ }^{5}$ A császár és a császárnő közötti beszélgetések, az intenzív együttlét ellenére - egy alkalmat leszámítva -, Mogiljovban még kerülték a politikai témákat. A beszélgetések a Szmolenszkbe vezető közös úton, illetve magában a városban már oldottabb hangulatúak voltak, jobban előkerültek a nagyhatalmi elképzelések, de az egyeztetések végső céljukat a közel három hetes pétervári tartózkodás során érték el. A téma feldolgozásához (kifejezetten a két uralkodó közötti párbeszédekre összpontosítva) az elsődleges forrásunk II. József anyjának írt levelei, amelyek Arneth munkásságának köszönhetően már régóta a történetírók rendelkezésére állnak. ${ }^{6} \mathrm{Ha}$ analóg módon bíznánk a II. Katalin által fiának - Pál nagyhercegnek ${ }^{7}$ - írt levelekben, hogy azokból is betekintést kaphatunk a két uralkodó politikai jellegú beszélgetéseibe, csalódnunk kell. ${ }^{8}$ Bár II. Józsefnek és Mária Teréziának sem volt felhőtlen a kapcsolata, ${ }^{9}$ II. Katalin és Pál között meglehetősen felületes és bizalmatlan volt a viszony, ami később a császárnak is feltűnt. ${ }^{10}$ Ugyancsak kevés haszonnal forgathatók II. József és II. Katalin egymásnak írt levelei, hiszen azok inkább

4 Falkenstein grófság a császár címei közül az utolsó volt. A témáról és kifejezetten II. József inkognitó utazásairól: Kulcsár Krisztina: II. József utazásai Magyarországon, Erdélyben, Szlavóniában és a Temesi Bánságban 1768-1773. (Doktori Mestermunkák). Budapest, Gondolat - Magyar Országos Levéltár, 2004. 24-31., 63.

5 Бессарабова, Н.В.: Путешествия Екатерины Великой по России і. m. 216-219.

6 Maria Theresia und Joseph II. Ihre Correspondenz sammt Briefen Josephs an seinen Bruder Leopold / Hrsg. von Arneth, A. Ritter von. Dritter Band. Wien, 1868. Az orosz történetírás szempontjából megemlítendő még Brikner, aki két részletben az orosz út során íródott leveleket (részletekben) oroszul is közölte. Брикнер, А.Г.: Путешествие Императрицы Екатерины II в Могилев в 1780 году. In: Русский Вестник. Т. 154. № 8. 459-509., Брикнер, А.Г.: Путешествие Императрицы Екатерины II в Могилев в 1780 году. In: Русский Вестник. Т. 155. № 9. 311-367.

7 Павел Петрович (1754-1801) I. Pál néven 1796-1801 között az Orosz Birodalom császára. III. Péter és II. Katalin fiaként látta meg a napvilágot, így Erzsébet cárnő halála után cárevics, azaz az Orosz Birodalom trónörököse lett. Erzsébet cárnő még életében különös gondot fordíttatott a nevelésére, mivel nem volt gyermeke, és őt szerette volna a trónra, ezért szüleitől elszakítva neveltette. II. Katalin hatalomra kerülése után igyekezett fiát távol tartani az állami ügyektől, így tulajdonképpen csak anyja halála után, 1796-ban jutott hatalmi pozícióba. Uralkodása azonban nem volt hosszú életü, ugyanis 1801. március 11/23-én éjszaka meggyilkolták, helyére fia ült a trónra I. Sándor néven. Брокгауз, Ф. А. - Ефрон, И. А.: Энциклопедический словарь. (a továbbiakban: ЭСБЕ), T. XXIla. 549-552.

8 Брикнер, А.Г.: Путешествие Императрицы Екатерины II T. 155. і. m. 318-319.

9 Témánkhoz kapcsolódó példa: Mária Terézia ellenezte II. József oroszországi utazását. Ezt előre sejtette a császár, ezért az út előkészítéséhez anyja és Kaunitz kancellár tudta nélkül fogott hozzá. Петрова, М. А.: Екатерина II. и Иосиф II. i. m. 126-128.

10 Maria Theresia und Joseph II. i. m. 271. 
hízelgésből és kedveskedésből állnak, mint politikai egyeztetésekből. ${ }^{11}$ Emellett még hasznunkra lehetnek egyéb levelek, amelyeket a két uralkodó vagy a közvetlen környezetükben állók írtak. Magáról az utazásról ennél jelentősen gazdagabb forrásanyag áll rendelkezésünkre, amelyek közül - kifejezetten magyar vonatkozása miatt - külön figyelemreméltó a II. József által magával vitt gyóntatópap, Kalatay Ferenc ${ }^{12}$ (későbbi nagyváradi püspök) úti beszámolója.. ${ }^{13}$

\section{Mogiljovi tartózkodás}

A két uralkodó közül a császár érkezett előbb Mogiljovba, méghozzá a cárnőnél 2 nappal korábban. ${ }^{14}$ Május 22-én/június 2-án teljes inkognitóban lépett a városba, ottléte, a források tanúsága szerint, még a város vezetősége számára is csak egy véletlennek köszönhetően derült ki. ${ }^{15} \mathrm{Ha}$ nem is zárkózott be teljesen, anyjának írt leveléből úgy tűnik, hogy csak a császárnő érkezésére koncentrált, más iránt alig érdeklődött. Még II. Katalin előtt, de egy általa írt levéllel érkezett a városba Grigorij Alekszandrovics Patyomkin ${ }^{16}$ herceg, illetve az oroszországi

11 A szintén Arneth munkásságának köszönhetően kiadott levélgyűjteményben négy olyan levél szerepel, amelyek az oroszországi út során keletkeztek (Hármat írt II. Katalin, és egyet II. József). Joseph II. und Katharina II von Russland. Ihr Briefwechsel. Hrsg. von Arneth, A. Ritter von. Wien, 1869. 6-10. A két uralkodó levelezéséről bővebben: Dinnyés Patrik: Az első levélváltás II. Katalin orosz cárnő és II. József német-római császár között. In: A pécsi ruszisztika szolgálatában. Bebesi György 60 éves. Szerk.: Bene Krisztián - Huszár Mihály - Kolontári Attila. Pécs, PTE BTK TTI MOSZT Kutatócsoport, 2018. 157-166.

12 Bár a mai oldalági rokonok a "Kalotay” formát használják, mi a korabeli írásmód alapján inkább a "Kalatay” alakot részesítjük előnyben. Szulovszky János: Hogyan lett regement káplánból nagyváradi püspök? Anekdoták és történeti adatok Kalotay Ferencről. In: Aranymadár. Tanulmányok Tánczos Vilmos tiszteletére. Főszerk.: Jakab Albert Zsolt. Kolozsvár, 2019. 881-891. A 888. oldalon rosszul szerepel a császár útvonala: „Mogiljov-Kijev-Szmolenszk-Mosz[k]va-Pétervár-Riga”. Az első két város fel van cserélve, hiszen előbb Kijev, és csak aztán Mogiljov volt az állomás. Hasonlóan Fejtő Ferenc is tévesen azt írja, hogy II. József és II. Katalin Szentpétervár felé „útközben Kijevben megtekintették a helyőrség hadgyakorlatát". Vélhetően Szmolenszkre gondolhatott a szerző. Fejtő Ferenc: Il. József. Budapest, Atlantisz Kiadó (reprint), 1997. 222-223.

13 Ez a primer forrás több változatban is fennmaradt, legutóbb Szulovszky János értekezett a szövegváltozatokról. Szulovszky J.: Hogyan lett regement káplánból nagyváradi püspök? i. m. 886-887.

14 Mogiljovtól Szmolenszkig i. m. 39-43.

15 Dinnyés P.: Mogiljovtól Szmolenszkig i. m. 43., Добрынин, Г. И.: Истинное повествование, или жизнь Гавриила Добрынина, им самим писанная. 17521823. In: Русская старина. Т.4. № 8. СПб., 1871. 110-111.

16 Григорий Александрович Потемкин (1739-1791) egyszerű katonatiszti családba született, karrierjének első jelentős állomásaként részt vett a katalini palotaforradalomban. II. Katalin az orosz-török háború kapcsán figyelt fel rá, és már 1771-ben közelebbi kapcsolatba kerültek, egyes feltételezések szerint később titokban össze is házasodtak. 1776-ban II. Katalin közvetett kérésére II. József Patyomkinnak a „Szent 
osztrák nagykövet, Johann Ludwig von Cobenz ${ }^{17}$ gróf. A katalini levélben és az arra íródott válaszban természetesen szó sem eshetett még semmilyen külpolitikai célokról vagy nagyhatalmi kérdésekről. A császárnő levele május 19-i/30-i keltezésű, míg a császár válasza május 22-i/jún. 2-i. ${ }^{18}$ Ez tehát megerősíti, hogy II. Józseffel azonos napon érkezett oda Patyomkin és Cobenzl is, sőt a válasz már aznap meg is született. A császárnak Patyomkin személyében egyébként lehetett volna olyan beszélgetőpartnere, akivel elkezdhette volna a külpolitikai jellegű eszmecserét, de a herceg kényesen került minden ilyenre irányuló lehetőséget, feltehetően II. Katalin utasítására. ${ }^{19}$

A császárnő május 24-én/június 4-én érkezett meg Mogiljovba. Minthogy a bevonulásáról és a II. Józseffel való első találkozásáról már korábban részletesebben írtunk, ${ }^{20}$ jelen esetben csak annyit említenénk meg, hogy az általunk ismert források ugyan eltérnek a részletekben, annyi biztosnak tűnik, hogy közvetlenül az első találkozás után, de még a közös étkezés előtt sor került egy szűkebb körű beszélgetésre a koronás fők között. Ennek sem pontos tartalma, sem időtartama nem tisztázott, a császár anyjának írt levelében is csak annyit említett, hogy az uralkodónő kedélyes hangulatú volt ugyan, de csak (II. József szempontjából) lényegtelen dolgokról esett szó. ${ }^{21}$ Ezt követően került sor - ahogy az együtt töltött többi napon is - egy nagy létszámú közös ebédre. Ahogy az étkezéseken, úgy az egyéb programokon is sok időt tölthetett együtt II. József és II. Katalin, azonban ezekre az alkalmakra ugyanúgy igaz lehetett az imént már említett józsefi levélrészlet: „kedélyes hangulatú, de semmi lénye-

Római Birodalom hercege" címet adományozta. Életét rengeteg könyv, színházi mű és film feldolgozta, mivel személyisége meglehetősen ellentmondásos. ЭСБE T. XXIVa, 728-730.; V. Molnár László: Kegyencek közt az első. Grigorij Patyomkin, 1739-1791. In: II. Katalin cárnő és az „északi kolosszus”. Tanulmánykötet. Szerk. V. Molnár László. Örökség. Kaposvári Kiskönyvtár 45. Kaposvár, 2014. 26-41.; Massie, Robert K.: Nagy Katalin - Egy asszony portréja. Budapest, 2018. 463-489.

17 Johann Ludwig von Cobenzl (1753-1808) apja 1753-tól 1770-ben bekövetkezett haláláig Osztrák Németalföld teljhatalmú minisztere volt. Ő maga Koppenhágában (1774), Berlinben (1777) és Szentpéterváron (1779-1797) volt nagykövet. 1801-1805 között a Habsburg Monarchia külügyének irányítója volt. Aktív szerepet játszott a forradalmi, majd a napóleoni Franciaországgal szemben. Az 1805-ös austerlitzi vereség és az azt követő pozsonyi béke után lemondott, és nyugdíjba vonult. Karrierjének pozitív alakulásához jelentősen hozzájárult oroszországi szolgálata, az orosz-osztrák szövetség kidolgozásában való tevékeny szerepe. Allgemeine deutsche Biographie. Bd. 4, Carmer - Deck. Leipzig, 1876.355-363; ЭСБЕ T.XVa.494.,Хаванова, О. В.:Австрийские послыи посланники при русском дворе в период охлаждения двусторонних отношений в 60-е - начале 80-х годов XVIII в. In: История, язык, культура центральной и юго-восточной Европы в национальном и региональном контексте. К 60-летию Константина Владимировича Никифорова. Москва, 2016. 60.

18 Петрова, М. А.: Екатерина II. и Иосиф II. і. m. 147., Joseph II. und Katharina II von Russland i. m. 6-8., Maria Theresia und Joseph II. i. m. 247-248.

19 Петрова, М. А.: Екатерина II. и Иосиф II. i. m. 149.

20 Dinnyés P.: Mogiljovtól Szmolenszkig i. m. 46-54.

21 Maria Theresia und Joseph II. i. m. 249. 
ges".22 A két uralkodó Mogiljovban május 30-ig/június 10-ig hét napot töltött egymás társaságában, de ez idő alatt csak egy alkalommal került elő a külpolitika mint téma. ${ }^{23}$ Erről a II. József által május 28-án/június 8-án Mária Teréziának írt levélből értesülhetünk, amelyben a császár öt pontban foglalta össze a szóban forgó beszélgetést: (1) a beszélgetések egyre inkább közvetlenek, amiből arra következtet a császár, hogy kezdi elnyerni a császárnő bizalmát; (2) II. Katalin vonakodik a politikai témáktól, II. Józsefnek meg kell ragadnia minden lehetőséget, hogy előkerüljön a téma; (3) a levél írását megelőző este (május 29/ június 9.) az operában sikerült beszélnie azokról a rossz hírét keltő pletykákról, amelyeket a porosz király terjesztett róla, de a császárnő bizonygatta, hogy ő nem ad hitelt ilyen szóbeszédeknek:24 (4) szóba került a tengeri fegyveres semlegesség, ${ }^{25}$ amivel nagyon meg volt elégedve az uralkodónő; (5) végül pedig II. Katalin megkérdezte a császárt, hogy nem akarja-e német-római császárként visszaszerezni Itáliát és Rómát megtenni fővárosává. Erre a császár előbb egy tréfás, majd egy komoly választ adott. Tréfásan, de nem minden ok nélkül jegyezte meg: a császárnő a "maga Rómáját”, azaz Konstantinápolyt sokkal könnyebben megszerezhetné. Ami viszont a császárt akadályozhatta volna az itáliai terjeszkedésben, az az, hogy a félszigeten a status quo megőrzése sok állam érdeke volt. A törökellenes fellépés lehetősége elől a császárnő kitért, és kijelentette, hogy csak a békére gondol. ${ }^{26} \mathrm{Az}$ említett beszélgetésen tehát első ízben került elő a két uralkodó között az úgynevezett "görög terv", ami az Oszmán Birodalom romjain, konstantinápolyi központtal restaurálandó Bizánci Birodalmat jelentette. ${ }^{27}$

Ismerve az előzményeket és a későbbi eseményeket, elmondhatjuk, hogy ezen az egy beszélgetésen - ha különböző mélységben is, de - felszínre került a két uralkodó minden olyan sérelme vagy vágya, amelynek orvoslásában a másikra számított volna. Röviden: Poroszország és az Oszmán Birodalom. Nehéz vagy éppenséggel lehetetlen csak a császár beszámolójából rekonstru-

22 Maria Theresia und Joseph II. i. m. 249.

23 Ezzel szemben az európai udvarok oroszországi képviselői úgy gondolták, hogy a két uralkodó egymás között kifejezetten a keleti kérdésről tárgyal. Брикнер, А.Г.: Путешествие Императрицы Екатерины II T. 154. і. m. 504.

24 Hogy pontosan milyen pletykákról van szó, az nem derül ki a levélből, és egyelőre a szakirodalomban sem lelhető fel erről semmi. Az viszont biztos, hogy e híresztelések foglalkoztatták II. Józsefet, mivel korábban is írta, hogy elsődleges feladatának tartja, hogy eloszlassa a negatív előítéleteket, amelyeket II. Frigyes terjesztett róla és a Habsburg Monarchiáról. Beales, Derek: Joseph II. In the Shadow of Maria Theresa, 1741-1780. Vol. 1. Cambridge, 1987. 434-435.

25 A Habsburgok ekkor még nem, csak 1782-ben csatlakoztak a tengeri fegyveres semlegesség nyilatkozatához. Már 1778-ban csatlakozott Franciaország, Spanyolország, 1780-ban Hollandia, Svédország és Norvégia, 1782-ben Ausztria mellett Poroszország, majd 1783-ban Portugália. Tóth-Barbalics Veronika: Sok hűhó Münchenért. (Harc a bajor örökség körül 1778-79-ben). In: Sic Itur Ad Astra. 2002. 3-4. 64.

26 Maria Theresia und Joseph II. i. m. 251-252.

27 Beales, D.: Joseph II. I. i. m. 433-434., Dinnyés P.: Mogiljovtól Szmolenszkig i. m. 53. 
álni ennek a beszélgetésnek a hangulatát, hangsúlyát és árnyalatait, de mindenképpen érdemes róla hosszabban gondolkodni. Az első két pont pusztán csak arról szól, hogy a császár és a császárnő között a bizalom kezd kiépülni, ami feltétlen szükséges ahhoz, hogy komolyabb témák is előkerüljenek beszélgetéseik során. A császárban az operai történések joggal kelthették azt a benyomást, hogy jó úton jár az uralkodónő bizalmának elnyerésében, amiben egyébként nem is tévedett, hiszen a császárnő valóban pozitívan vélekedett a császárról. ${ }^{28}$ II. József Mogiljovból nem haza, hanem az uralkodónővel együtt Szmolenszkbe indult. A terv az volt, hogy a város elhagyásakor szétválnak: a császárnő egyenesen Szentpétervárra, míg a császár Moszkvába, majd onnan ő is Szentpétervárra veszi az irányt. ${ }^{29}$

\section{A Mogiljovból Szmolenszkbe vezető út}

Arról, hogy a Szmolenszkbe vezető úton miről beszélgettek az uralkodók, első körben szintén a császár június 3-án/14-én anyjának írt leveléből szerezhetünk tudomást. ${ }^{30}$ Ebből a levélből az is kiderül, hogy a korábbi napokhoz képest is intenzívebb volt az együtt töltött idő, hiszen a két és fél napos utat a császár az uralkodónő hatszemélyes kocsijában tette meg. ${ }^{31}$ A császár az utat a kocsi miatt kényelmesnek, a császárnő miatt pedig kellemesnek írta le, hiszen benne egy nagyon kedves és múvelt személyt ismert meg. ${ }^{32}$ Emellett természetesen különböző programok tarkították az utat, a nagylétszámú étkezésektől kezdve a különböző ünnepségeken át a bálokig és színdarabokig fellelhető volt minden. Hogy a két és fél napos út során mikor és hol került sor a mélyebb diskurzusra, illetve hogy egyben vagy több részletben, azt nem tudjuk biztosra megmondani. Vélhetően nem az utazás azon részén, amikor a kocsiban többen is ültek, és talán a császár is arra utal, hogy a programok adták a lehetőséget a komolyabb témák előkerülésére. ${ }^{33}$

28 Бессарабова, Н.В.: Путешествия Екатерины Великой по России і. m. 222.

29 Dinnyés P.: Mogiljovtól Szmolenszkig i. m. 54-58.

30 Maria Theresia und Joseph II. i. m. 256-257.

31 A kocsiban még helyet foglaltak: Alekszandra Vasziljevna Engelhardt grófnő, Johann Philipp Cobenzl (miniszter), Alekszandr Dmitrijevics Lanszkoj (II. Katalin kegyence), Lev Alekszandrovics Nariskin (főlovászmester), és a város elhagyása után csatlakozhatott Zahar Grigorjevics Csernyisov (főkormányzó). Korábban A. V. Engelhardt grófnőt mint lehetséges útitársat - Dobrinyin alapján - tévesen Branyickaja grófnőként említettük, holott a grófnő csak 1781-ben ment feleségül Franciszek Ksawery Branicki lengyel nagyhetmanhoz, így ezt megelőzően leánykori nevén említendő. Brikner tehát minden bizonnyal ezért jelölte hibásnak Dobrinyin közlését, nem pedig a korábban általunk állított ok miatt. Добрынин, Г. И.: Истинное повествование i. m. 212-213., Брикнер, А.Г.: Путешествие Императрицы Екатерины II T. 155. i.m. $311 .$, Dinnyés P.: Mogiljovtól Szmolenszkig i. m. 58-59.

32 Maria Theresia und Joseph II. i. m. 256.

33 Maria Theresia und Joseph II. i. m. 257. 
A császár három pontban foglalta össze a beszélgetés(ek) tartalmát: (1) Ismét felhozta a porosz király által terjesztett hamis pletykákat, amire az uralkodónő újfent megerősítette, hogy ő azoknak nem hisz. A témáról való beszélgetés hangulatát segít elképzelni a császár további megjegyzése: „A részletekbe nem bonyolódtunk bele, kényelmetlennek éreztem már a panaszkodást, és nem akartam a császárnőt sem kényelmetlen helyzetbe hozni". ${ }^{34}$ (2) A császár közölte, anyjával úgy döntöttek, hogy minden fontos kérdésben értesítik a császárnőt, és tanácsot is szívesen vesznek tőle. Ez II. Katalinnak felettébb imponálhatott, a válasza is legalább ilyen hízelgő volt: nagyon szívesen veszi, ha hozzá fordulnak, és garantálja, hogy a kérdésekkel személyesen ő fog foglalkozni legjobb képességei szerint. ${ }^{35}$ Felmerülhet a kérdés, hogy ezen kijelentések előtt egyeztetett-e a császár édesanyjával, közösen gondolták-e ki azokat. Ha csak "udvarlási” formuláról van szó, akkor aligha történt egyeztetés, és akkor a jelentősége sem olyan nagy ezeknek a szavaknak. Azt tudjuk, hogy az utazást követően nagyon intenzív levelezőkapcsolat alakult ki a két uralkodó között, de mivel mi ebből a gazdag forrásanyagból csak az oroszországi úttal kapcsolatos leveleket tudtuk feldolgozni, arra a kérdésre még nem tudjuk a választ, hogy alapvetően milyen jellegűek ezek a levélváltások. ${ }^{36}$ Mindenesetre Mária Terézia II. Katalinról alkotott negatív véleményének ismeretében aligha képzelhető el, hogy őszintén vágyott egy ilyen szoros együttműködésre. ${ }^{37}$

Végül II. József a leghosszabban tárgyalt (3) pontot azzal vezeti fel, hogy amikor látta, hogy már II. Katalin is kerülgeti a törökökkel kapcsolatos témát, akkor megemlítette a legutóbbi orosz-török háborút, a törökökkel kezdődő osztrák kapcsolatokat és a porosz király által tett nyilatkozatot. ${ }^{38} \mathrm{~A}$ császár elmondása

34 Maria Theresia und Joseph II. i. m. 257.

35 Maria Theresia und Joseph II. i. m. 257.

36 A két uralkodó közel 200 levelet váltott egymással az 1780-as út és a császár halála közötti 10 évben. Alfred Ritter von Arneth 1869-ben II. Katalin cárnő és II. József császár levelezéséből összesen 181 levelet publikált. Ebből 96 II. Kataliné, és 85 II. Józsefé. 1880-ban (tehát az első út 100. évfordulóján) ezen osztrák kiadás alapján jelent meg egy orosz fordítás Ivan Mihajlovics Zsivago által, ami azonban csak 97 levelet tartalmazott: a cárnőnek 48, míg a császárnak 49 levele kapott benne helyet. Érdekes és egyben sajnálatos módon a két kiadás közötti különbözőségek érintik a császár utazásait is, hiszen például az Arneth által közölt kiadványban szereplő 4 levél, amelyek 1780. május 19. és 1780. július 19. között - tehát II. József első oroszországi útja során - íródtak, nincsenek benne az orosz fordításban. Joseph II. und Katharina II von Russland. i. m., Живаго, И.м.: Переписка Екатерины Великой с Германским императором Иосифом II-м. 1774-1790. In: Русский архив. Историко-литературный сборник. 1880. 210-355.

37 Петрова, М. А.: Екатерина II. и Иосиф II. i. m. 128.

38 Itt talán arról lehet szó, hogy a porosz király semmi szín alatt nem volt hajlandó támogatni egy újabb orosz akciót a törökök ellen, amit nyíltan fel is vállalt az orosz udvarban: II. Frigyesnek (ahogy korábban Franciaországnak) szüksége volt a törökökre a Habsburgok féken tartása érdekében. A poroszokra nézve a legrosszabb forgatókönyv szerint pedig egy törökellenes háborúban II. Katalin éppen II. Józsefben találhatna szövetségesre. Schwicker János Henrik: Magyarország s a bajor örökösödési háború. Bp., Athenaeum, 1878. 9. 
szerint a téma előkerülése nyugodttá tette a császárnőt, és őszintén elmondta, hogy aggódik az osztrák-török közeledés miatt. A császárnő azt is elmondta, hogy népe még jobban sérelmezi, mint ő, hogy a legutóbbi török háborúban nem segítettek nekik. Minden bizonnyal ez - véli a császárnő - a franciák munkájának az eredménye, hiszen náluk senki sem szereti jobban a törököket Európában. „Ilyen ideális idő, ennyire tökéletes lehetőség lehetséges, hogy soha többé nem adódik." ${ }^{39}$ II. József erre válaszként a kitartó porosz szövetségüket hozta fel, amit a császárnő azzal hárított el, hogy hatalomra kerülésekor nem vágyott másra, csak békére, a porosz szövetség pedig ennek az öröksége. Ismét előkerült Róma mint császári központ, amire II. József (mint eddig bármikor, ha ez feljött) gúnyosan Konstantinápolyt adta válaszként. Egyszer azonban erre azt válaszolta II. Katalin, hogy ha egyszer megszerzi, akkor nem fogja megtartani magának. Ezt így kommentálta a császár: „Mindebből arra következtetek, hogy megosztaná saját birodalmát, és a Keleti Birodalmat az unokájának, Konstantinnak adná."40

De II. József nemcsak II. Katalinnal beszélgetett útközben, hanem például $A$. A. Bezborodkóval ${ }^{41}$ is, aki már Szmolenszkből, ugyanazon a napon, amikor a császár írt anyjának, június 3-én/14-én erről egy levélben számolt be. Fontos, külpolitikát érintő kérdésekről is beszéltek, de világossá válhatott az is II. Józsefnek, hogy bár hivatalosan még Ny. I. Panyin ${ }^{42}$ a külügyekért felelős miniszter, már alig

39 Maria Theresia und Joseph II. i. m. 258.

40 Maria Theresia und Joseph II. i. m. 258.

41 Александр Андреевич Безбородко (1747-1799) jó képességü, tehetséges diplomata hírében állt. Az orosz nyelven kívül beszélt franciául, németül, románul, görögül és latinul. Ny. I. Panyin menesztése után tulajdonképpen ő vezette az Orosz Birodalom külpolitikáját, I. Pál uralkodása alatt első osztályú valóságos titkos tanácsos, majd haláláig kancellár lett. Orosz részről a Lengyel-Litván Nemesi Köztársaság felosztásának egyik legnagyobb kezdeményezője, illetve a törökellenes háború egyik legfőbb támogatója volt. ЭСБЕ, Т. III, 269-270.; Турилова, С. Л.: Руководство внешней политикой Росси. In: История внешней политики России XVIII век. От Северной войни до войн против Наполеона. Отв.ред.: Санин, Г.А. Москва, Международные отношения, 1998. 261-262.

42 Никита Иванович Панин (1718-1783) olasz ősökkel rendelkező család sarja, amely a 17. században már jelentős politikai körökben mozgott. Nyikita Panyin Anna Ivanovna cárnő uralkodása alatt kezdte katonai pályafutását, de később diplomata pályára lépett. Erzsébet cárnő uralkodása alatt Alekszej Petrovics Besztuzsev-Rjumin kancellár pártfogoltja volt. 1760-ban Erzsébet cárnő Pál nagyherceg nevelőjének nevezte ki, az uralkodónő bizalmi embere lett. Karrierje tovább emelkedett III. Péter rövid, majd II. Katalin hosszú uralkodásának első felében. Jelentős szerepet játszott II. Katalin hatalomra jutásában. Pállal élete végéig jó kapcsolatot ápolt, eredetileg II. Katalint csak mint régenst képzelte el a trónon, amíg Pál nagykorú nem lesz. Az orosz-osztrák szövetség újbóli feléledése kapcsán kegyvesztetté vált, a politikától visszavonultan halt meg. Гаврюшкин, А. В.: Граф Никита Панин. Из истории русской дипломатии XVIII века. Москва, 1989.; Минаева, Н. В.: Никита Иванович Панин. Вопросы Истории, (2001) №7. 71-911.; Dinnyés Patrik: Az orosz külügyek irányítója: Nyikita Ivanovics Panyin (1718-1783). Szerk. [S.n.] Új Nemzedék. Pécs, 2018. 29-44. 
van szerepe az udvarban. ${ }^{43}$ A császárnak feltűnt, hogy A. A. Bezborodko egyre inkább úgy viselkedett, mintha már ő lenne kinevezve Panyin gróf posztjára, nyíltan beszéltek Panyinról, de szóba jött Kaunitz kancellár is. Brikner és Ny.V. Besszarabova is arra a megállapításra jutott, hogy II. József A. A. Bezborodko személyében jó beszélgetőtársa talált, még ha - és ezt már csak Ny. V. Besszarabova jegyzi meg - túlzottan jó véleménnyel nem is volt róla. ${ }^{44}$

A vágyott téma kibontakozása után talán nem is volt annyira a császár kedvére a moszkvai kitérő, de az is elképzelhető, hogy jól is jött neki egy kis felkészülési idő az ügy várt végkifejlete előtt. A levél írásakor egyébként még azt gondolta, hogy moszkvai kísérője, Patyomkin herceg majd a császárnő utasítására puhatolózni fog a császár külpolitikai nézetei felől, de erre végül nem került sor, Patyomkin alig mutatkozott a császárral Moszkvában, mindössze háromszor találkoztak a hét nap alatt. ${ }^{45} \mathrm{Az} 1780$-as út diplomáciai csúcspontja a szentpétervári tartózkodás alatt következett be. ${ }^{46}$

A háromnapos szmolenszki tartózkodás után, június 4-én/15-én ${ }^{47} 9$ órakor, a bevonulásnál adott tiszteletadáshoz hasonló körülmények között, a kormányzó kíséretében elindult II. Katalin Szentpétervárra, miután pedig a császárnő elhagyta a várost, gróf Falkenstein is elindult Moszkvába. ${ }^{48}$

\section{Szentpétervár}

II. József június 17-én/28-án ért Szentpétervárra. ${ }^{49}$ Kalatay Ferenc az általunk ismert összes beszámolójában a Pétervárra érkezés dátumát tévesen június 27-re teszi. Ez alól egy kivétel van, mégpedig a Tudományos Gyűjteményben

43 A panyini „északi összhang” külpolitikai doktrínának a „görög terv" vetett véget. Мадариага, Исабель де: Россия в эпоху Екатерины Великой. Пер. с английского Н. Л. Лужецкой. Москва, 2002. 610.

44 Брикнер, А.Г.: Путешествие Императрицы Екатерины II Т. 155. і. m. 313-315., Бессарабова, Н.В.: Путешествия Екатерины Великой по России і. m. 218.

45 Петрова, М. А.: Екатерина ІІ. и Иосиф II. і. m. 156.

46 A szmolenszki tartózkodás alatt a császár semmiképpen sem kívánta siettetni az események alakulását, ugyanis meg volt róla győződve, hogy jó az irány, a pétervári várhatóan - kötetlenebb együttlét pedig majd meghozza gyümölcsét. Maria Theresia und Joseph II. i. m. 258-259.

47 Дневная записка путешествия Императрицы Екатерины II в Могилев. In: Сборник Русского Исторического Общества, Т. 1. СПб., 1867. 384-420. 413. Brikner egy oldalon három elütést is vétett: előbb tévesen július 4-ét írta az indulás dátumának, majd egy II. Katalin által, Precsisztojéból írt levelet keltezett július 5-re, majd a császárnő Novgorodba érkezésének június 11. helyett július 11-et írt. Брикнер, А.Г.: Путешествие Императрицы Екатерины II T. 155. і. m. 320-321.

48 Journal der Russlandreise Kaiser Joseph II. im Jahre 1780. Hrsg. von E. Donnert - H. Reinalter. Innsbruck, 1996. 9.

49 A császár június 6-án/17-én érkezett Moszkvába, ahol hét napot töltött. Eredeti terveitől eltérően egy nappal tovább maradt, és június 13/24-én hagyta el a várost. Journal der Russlandreise Kaiser Joseph II. i. m. 9-21., Maria Theresia und Joseph II. i. m. 262. 
1823-ban megjelent, Reviczky bárónak címzett változat, amelyben helyesen 28-a szerepel, sőt még azt is hozzátette, hogy az út "4 nap' és 4 éjtszaka' tartott". ${ }^{50}$ Ahogy azt már említettük, a császár moszkvai tartózkodása alatt nem történt előrelépés a diplomáciai ügyekben, de arra elegendő volt, hogy az uralkodó felkészüljön: Szentpéterváron már sokkal nyugodtabban és természetesebben tudott viselkedni, aminek leginkább az lehetett az oka, hogy már körülbelül tudta, mit várhat a császárnőtől. ${ }^{51}$

A fővárosban és környékén töltött 3 hét olyan hosszú idő, hogy részletekbe menően jelen keretek között nincs lehetőségünk elmerülni a politikai játszmákban, amelyek itt már végképp nem csak a két uralkodót érintették. ${ }^{52}$ Tartva az eddigi fókuszt, továbbra is csak a két uralkodó közötti politikai kapcsolat alakulására összpontosítunk, de itt is szükséges a téma összesítése, hiszen a fő forrásunknak tekinthető, II. József által Mária Teréziának írt levelekből 10 darab született június 17/28. és július $7 / 18$. között. ${ }^{53}$

A császár pétervári tartózkodásával kapcsolatban annyit mindenképpen szükséges megemlíteni, hogy megérkezésekor Cobenzl Néva-parti házában szállt meg. ${ }^{54}$ Másnap reggel utazott ki a Szentpétervártól délre fekvő Carszkoje Szelóba, ahol várta és vendégül látta a császárnő. ${ }^{55} \mathrm{~A}$ harmadik napon a teljes uralkodói család és a jeles vendég kíséretével átköltözött a fővárostól keletre, a Finn-öböl partján fekvő Peterhofba, ahol egészen az elutazásig tartózkodtak. Már az első három napban is, és azt követően is az adott szálláshelyről időnként a fővárosba vagy egyéb környező helyekre utaztak különböző eseményekre, programokra. ${ }^{56}$

50 Érdekes ez az eltérés, ugyanis az eddig legalább hét alkalommal, különböző helyen és időben kiadott forrásnak a címzés és a keltezés alapján eddig három változatát különböztethettük meg: (1) budai ismerősöknek aug. 22-én; (2) budai ismerősöknek aug. 23-án; (3) egri ismerősöknek pontos dátum nélkül. Az említett eltérő dátummal azonban most már négy típusát különböztethetjük meg az egyes változatoknak ([4] budai ismerősöknek aug. 22-én, jún. 28-i érkezéssel Pétervárra). Szulovszky J.: Hogyan lett regement káplánból nagyváradi püspök? i. m. 886.

51 Петрова, М. А.: Екатерина II. и Иосиф II. i. m. 159-160.

52 II. József ugyanis itt sem csak II. Katalinnal beszélgetett politikáról, hanem udvarának több befolyásos emberével is, sőt a trónörökössel, valamint pétervári külföldi követekkel is. Emellett Cobenzl és Patyomkin között is folytak egyeztetések, de nem mellékesek a bécsi orosz követ, D. M. Golicin és Kaunitz, illetve Mária Terézia közötti érintkezések sem.

53 Az Arneth-féle kiadásban ez 25 oldalnyi szöveget jelent. Gyakorlatilag kétnaponta íródott egy levél, de volt, hogy három egymást követő nap mindegyikén is. Maria Theresia und Joseph II. i. m. 262-287.

54 Molitor Ferenc tévesen írja, hogy „Cobenzl Néva-parti házában megszállva három hetet töltött”. Molitor Ferenc: II. József a császári Don Quijote. Budapest, Gondolat, 1987. 173.

55 Azt megjegyzi a császár, hogy nem a palotában kapott szállást. Bár ennek nem derül ki az oka, lehet a császár külön kérése vagy a császárnő figyelmessége II. József egyszerűség iránti szeretetére. Maria Theresia und Joseph II. i. m. 264.

56 Franciscus Xaverius Kalataynak, Praepost' Báró Rewiczky Urhoz, Löwenbergből datalt és kűldött Levele; mellyben, néhai b.e. II. József Császár' és Király’ 1780 Eszendőbéli, Muszka Országba tett útazását írja. Szerk.: Ponori Thewrewk Miklós. In: Tudományos Gyűjtemény. X. Kötet. Pest, 1823.33-34. 
A császár első, fővárosból írt levelét már megérkezése napján feladta, abban pedig még leginkább moszkvai élményeiről mesélt. ${ }^{57} \mathrm{~A}$ következő levelet június 20-án/július 1-jén írta, ezzel kapcsolatban viszont Brikner megjegyzi, hogy nem saját futárral küldte el, mint addig, hanem az állami postával. Ebből kifolyólag a levél sokkal kevésbé közvetlen és a tartalma is taktikusan nagyon pozitív és dicsérő, hiszen a császár feltételezi, hogy ezt a levelet a császárnő is olvasni fogja. ${ }^{58}$ Ezzel szemben a következő levél ismét sokkal közvetlenebb, és gyakorlatilag egyből rátér a lényegre: az elmúlt napok politikai témájú beszélgetéseire.

A június 23-án/július 4-én kelt levél az egész oroszországi utazás során íródott leghosszabb levele II. Józsefnek. Számunkra jelen esetben azért is lényeges forrás, mert gyakorlatilag az egész politikai tartalmú. Tekinthető a szentpétervári politikai játszmák bevezetőjének, ezért is érdemes kicsit részletesebben áttekinteni. A császár először arról ír, hogy a császárnő és környezete továbbra is barátságos és kedves vele. II. József megemlíti, hogy kifejtette II. Katalinnak a Kaunitz által kiépített külpolitikai szisztémát, majd pedig 9 pontban foglalja össze beszélgetéseik témáit: (1) a császárnő már nem neheztel a legutóbbi török háborúban tanúsított ellenséges osztrák magatartásért, úgy gondolja, a tescheni békével ${ }^{59}$ kiegyenlítették a számlát; (2) nem áll már messze attól, hogy a Habsburgokat a porosz királlyal azonos szinten kezelje, de utóbbival nem szeretné, ha megromlana a kapcsolata; (3) nagyon sajnálja, hogy az angolok ilyen nehéz helyzetbe kerültek, de szerinte ezért a király gyengesége és a minisztérium hibái a felelősek; (4) a francia- és spanyolországi helyzettel viszont éppen ellenkezőleg - meg van elégedve, és egyetért a francia király magatartásával; (5) szerinte Svédország és a svéd király is elégedetlen a helyzetükkel; (6) az eddigi pontokhoz képest sokkal hosszabban ír a császárnő terveiről, a Keleti Birodalom feltámasztásáról, amely kapcsán nem érti, hogy a franciák és a poroszok miért nem támogatják őt; (7) Itália és Róma kérdése, amit a császárnő szüntelen felhoz neki, sőt már Patyomkin is beszélt erről Cobenzllel; (8) Nyikita Ivanovics Panyin gróffal való beszélgetései; (9) Patyomkin szerepe. Nem jelöli külön ponttal, de egy egész bekezdést ír a nagyhercegről és feleségéről, közös beszélgetéseikről és programjaikról. II. József láthatóan igyekezett kiépíteni a kapcsolatot Pál nagyherceggel és feleségével, ami maximálisan érthető, hiszen joggal gondolhatta, hogy néhány éven belül mindketten egyeduralkodóként állnak majd államaik élén. ${ }^{60} \mathrm{~A}$ hosszú levél következő, egyben utolsó bekezdésében pedig egyebek mellett arról olvashatunk, hogy a császárnő oly szintű bizalommal tüntette ki a császárt, hogy elmesélte neki hatalomra jutásának

57 Ennek a levélnek van kifejezetten magyar vonatkozása is, ugyanis a császár megemlíti, hogy már amikor indult Moszkvából, akkor értek oda az anyjának levelével a futárok, akik közül az egyik egy bizonyos „Esterházy tiszt". Hogy pontosan kiről lehet szó, azt még nem sikerült kideríteni. Maria Theresia und Joseph II., i. m. 262.

58 Брикнер, А.Г.: Путешествие Императрицы Екатерины II T. 155. і. m. 325.

59 A bajor örökösödési háborút (1778-1779) lezáró béke.

60 Az utazás folytatása mellett szóló érv volt a részéről, hogy megismerkedhet a trónörökössel. Maria Theresia und Joseph II i. m. 259. 
körülményeit, III. Péter szörnyűségeit, és hogy mit volt kénytelen megtenni. ${ }^{61}$ Az imént vázlatosan ismertetett levél betekintést nyújt a Szentpéterváron töltött három hét alatt a császár által megélt, tapasztalt játszmákba. A továbbiakban ezeken a szálakon halad a diskurzus főként a két uralkodó, de Patyomkin és Cobenzl, illetve további szereplők között is. ${ }^{62}$

Az útnak feltétlen eredménye volt, hogy II. József és II. Katalin felmérhette, mit várhat el a másiktól, miben lenne partner a másik, és miben nem. Volt-e nyertese, vagy nagyobb nyertese a találkozónak? Napjaink orosz történetírásában van rá példa, hogy az orosz uralkodónőt eleve vezető szerepbe állítják a két uralkodó közül. ${ }^{63}$ Végső soron az is igaz, hogy a császár poroszellenes vagy bajor örökségért kifejtett újabb próbálkozásai sem hoztak sikert, sőt belekerült egy törökellenes háborúba. De azt se felejtsük el, hogy II. Katalin hiába hozta fel többször is a császárnak Rómát, aminek egyértelmúen az volt a célja, hogy az osztrák külpolitikai törekvéseket eltérítse Poroszország felől, ezzel biztosítva a békét Oroszország szomszédai között. Természetesen ez is a nagy célt hivatott szolgálni: teljes erővel az Oszmán Birodalom ellen. II. Katalinnak azonban nem sikerült elültetnie az itáliai terjeszkedés gondolatát II. József fejében, pedig még az is felmerült, hogy az oroszok feltétel nélkül szavatolnak minden osztrák hódítást, leszámítva természetesen a Német-római Császárság és Lengyelország területén. ${ }^{64}$ Emellett azt sem szabad elfelejteni, hogy a császár és Pál nagyherceg között sem volt sikertelen a kapcsolatépítés, hiszen a következő évben, amikor a nagyhercegi házaspár európai körútra ment, Bécsben II. József meghívására két alkalommal is megfordultak, ami Európa jövőjének építése szempontjából nem csak a fiát hatalomból tudatosan és szándékosan kizáró II. Katalin számára lehetett aggasztó. ${ }^{65}$

A 18. század második fele két jelentős uralkodójának személyes találkozása nem mindennapi esemény volt Európa történetében. Annak ellenére, hogy a két császárban a közösnek - némi fenntartással ugyan, de - csak németségük és abszolutisztikus uralkodói mentalitásuk volt tekinthető, II. Józsefnek és II. Katalinnak sikerült a mogiljovi és szmolenszki, majd pedig pétervári együttlétük alatt olyan viszonyba kerülniük, hogy - bár a külpolitikai elképzeléseik még távol álltak a közös nevezőtől - az 1780-as évek Közép-Kelet-Európáját egyre

61 Maria Theresia und Joseph II. i. m. 267-273.

62 Петрова, М. А.: Екатерина II. и Иосиф II. і. m. 158.

63 Arra hivatkozva, hogy eleve II. József volt, aki utazott, nem pedig II. Katalin, illetve hogy a beszélgetések témáinak alakulása is inkább a császárnő kedve szerint történt. Петрова, М. А.: Екатерина ІІ. и Иосиф II. і. m. 151.

64 Előbbiben Poroszország miatt, utóbbiban pedig azért, mert az oroszok saját érdekeltségnek tartották. Maria Theresia und Joseph II. i. m. 278-279.

65 Pál nagyherceg bécsi tartózkodásáról bővebben magyarul: Khavanova, Olga: Pavel Petrovics orosz nagyherceg bécsi látogatása 1781-1782-ben. In: Aetas. 34. évf. (2019) 3. sz. 72-83. Az európai körútról általánosságban: Зазулина, Н. Н.: Миссия великого князя. Путешествие Павла Петровича в 1781-1782 годах. Москва, 2015. 
inkább az orosz-osztrák közös érdek határozhatta meg. Mindez természetesen nem érthető meg a nagyobb európai kontextus nélkül, de reméljük, hogy az itt bemutatott adalék megfelelő kiegészítője lehet ismereteinknek erről a rövid, ámbár diplomáciai kapcsolatokban termékeny időszakról. 